\title{
A POSSIBILIDADE DE REPARAÇÃO POR DANO MORAL DECORRENTE DO ABANDONO PARENTAL ${ }^{1}$
}

THE POSSIBILITY OF THE REPAIR OF MORAL DAMAGE ARISING FROM PARENTAL ABANDONMENT

Rafael Garcia BATISTA ${ }^{2}$

Ana Cristina GOMES ${ }^{3}$

ISSUE DOI: $10.21207 / 2675-0104.2018 .792$

\begin{abstract}
RESUMO
O objeto deste artigo consiste na abordagem em torno do abandono parental e mostrar que este merece a apreciação do Poder Judiciário, de que deve ser lhe atribuído a compensação material nos casos em que houver sido constatado a omissão do genitor no que diz respeito ao dever de cuidado com o seu filho, por consequente, caracterizando um dano moral pertinente a sua dignidade da pessoa humana. A responsabilidade civil, é uma novidade no âmbito do direito das famílias, tema este que não foi discutido até recentemente. $\mathrm{O}$ abandono parental causa um rompimento no elo da família, causa uma quebra da confiança construída entre seus membros, sendo assim, não a convivência entre pai e filho, podendo ser porque este não a quer ou porque construiu uma nova família, a qual não permite a participação da prole advinda de uma família anterior, cenário que pode causas diversos problemas na criança ou adolescente vítima deste. Vários fatores podem ser associados ao abandono parental, já que
\end{abstract}

\footnotetext{
${ }^{1} \mathrm{O}$ presente artigo sintetiza a monografia de conclusão da pesquisa, realizada para o Programa Interno de Bolsas de Iniciação Científica (PIBIC 2017-2018) da Faculdade de Direito de Franca (FDF), Franca/SP.

${ }^{2}$ Discente da Faculdade de Direito de Franca (FDF), Franca/SP. Bolsista do Programa Interno de Bolsas de Iniciação Científica (PIBIC 2017-2018).

${ }^{3}$ Possui graduação em Direito pela Faculdade de Direito de Franca (1986) e mestrado em Direito pela Graduada em Direito pela Universidade Estadual Paulista "Julio de Mesquita Filho", Mestre em Direito pela Universidade Estadual Paulista "Julio de Mesquita Filho", doutoranda pela Universidad de Salamanca na Escuela de Doctorado - Estado de Derecho y Gobernanza Global, professora colaboradora da Faculdade de Direito de Franca (FDF), Franca/SP.
} 
este faz uma ruptura no laço fraternal criado entre pai e filho, sendo assim, é dever do direito usar de sua força coercitiva para fazer que cesse os atuais casos bem como prevenir aqueles que possam vir ocorrer.

Palavras-chave: Abandono parental. Responsabilidade civil. Filhos. Dano moral. Compensação material. Genitores.

\begin{abstract}
The objective of this article consists in the approach about the parental abandonment and to show that deserves the appreciation of the Judiciary it must be assingned the material compensation in those cases that has been verified the omission of the parent with respect to your duty to care for your child, consequently characterizing the moral damage pertinent to their dignity of the human person. The civil responsability is a novelty in the area of family law, this subject wasn't discussed until recently. The parental abandonment causes a rupture in the family bond and a break in the confidence built between its members, so there is no relationship between father and son either because is doesn't want to or because it has built a new family which doesn't allow the participation of the child from a previous family, this scenario can cause so many issues to the child or to the teenager victim of this. Many factors can be associated to parental abandonment, since it makes a fraternal rupture between father and child, so it is the duty of the law to use its coercive force to make it stop these present cases and to prevent those ones that may occur.
\end{abstract}

Keywords: Parental abandonment. Civil responsability. Children. Moral damage. Material compensation. Parents

\title{
1 INTRODUÇÃO
}

A família é a base para a construção plena da criança ou do adolescente, pois, é neste momento em que o individuo terá noção dos valores aceitos pela sociedade bem como dos seus deveres como cidadão da mesma.

O abandono parental quebra tanto a base, pois, a partir deste momento a criança pode vir a desenvolver diversos problemas comportamentais como o elo de confiança entre genitor e prole. Não há mais uma relação fraternal entre os dois lados, já que a criança foi abandonada, este pensamento gera inúmeros danos a psique, a ruptura causada pelo abandono parental é impossível de ser restaurada, mesmo que seja concedida a criança meios para acalentar esta dor e é dever do Poder Judiciário fazer com que tais casos sejam cessados.

Porém não é dever do direito obrigar um pai ou mãe a amar seus filhos, mas deste mesmo modo, pode o direito usar de sua força coercitiva para fazer com que o pai omisso assista seu filho nos seus momentos mais importantes de sua vida, provendo o que lhe é de direito bem como aquilo que a sociedade nos faz desejar. 
Diante do exposto, a Constituição Federal encontrou meios de fazer com que a criança e o adolescente sejam postos a salvo de qualquer conduta que venha a diminuir os seus direitos.

Portanto, para que tais esforços sejam almejados é necessário que os Tribunais Superiores façam uma análise minuciosa para ver o que caracteriza e ocasiona o abandono parental e constatar o nexo que liga a conduta do agente ao dano sofrido, para enfim conceder uma compensação material a vítima.

\section{O ABANDONO PARENTAL}

O abandono afetivo ocorre na maioria das vezes após a separação dos cônjuges, quando a concessão da guarda filho é cedida para algum dos pais e como consequência dessa separação, o genitor que não detém a guarda do filho começa a se ausentar, não cumprindo com as suas obrigações e deveres que já foram declarados pelo ordenamento jurídico, por vezes, acaba que esse genitor constitui uma nova família e por isso ou por uma não aceitação da nova família, acaba deixando o seu primogênito de lado para se dedicar a outra família, e isso é essencialmente o abandono afetivo.

Podemos citar uma passagem de Paulo Lobo em seu livro Direito Civil Famílias, no qual ele conceitua como sendo o "abandono afetivo" nada mais é do que uma obrigação que não foi cumprida pelos pais da criança, por tal fato, leva a gerar uma responsabilidade civil por parte deles. Diz Paulo Lobo, tendo como base a Doutrinadora Ana Carolina Brochado Teixeira:

Portanto, o "abandono afetivo" nada mais é que inadimplemento dos deveres jurídicos de paternidade. Seu campo não é exclusivamente o da moral, pois o direito não o atraiu para si, conferindo-lhe consequências jurídicas que não podem ser desconsideradas. Por isso, seria possível considerar a possibilidade da responsabilidade civil, para quem descumpre o múnus inerente ao poder familiar. "Afinal, se uma criança veio ao mundo desejada ou não, planejada ou não - os pais devem arcar com a responsabilidade que esta escolha (consciente ou não) lhes demanda. ${ }^{4}$

\footnotetext{
${ }^{4}$ TEIXEIRA, Ana Carolina Brochardo. Responsabilidade Civil e Ofensa à Dignidade Humana. Revista Brasileira de Direito de Família. Porto Alegre, 36 Edição, p. 156
} 
Se encontra em tramite no Senado o Projeto de Lei $n^{\circ}$ 700/2007, vem por dizer que o pai e a mãe que não detêm a guarda de seus filhos tem a obrigação de visita-los, desfrutar da companhia uns dos outros, auxilialos tanto financeiramente como educacionalmente, orientando aqueles que são menores de 18 anos, pois, eles não têm uma capacidade completa para escolher o que seria melhor para sua educação e para posteriormente seu futuro profissional, cabendo aos pais então ajuda-los no momentos de dor e sofrimento sempre que for possível, pois, com alguns entendimentos de tribunais superiores, caso os pais descumpram alguns desses deveres, ele poderá responder judicialmente por seus atos.

A pensão alimentícia e a compensação material não são fatores que encerram os deveres como pais e mães, é dever de ambos prestar uma assistência emocional aos filhos, independente da distância que estes se encontrem. $\mathrm{O}$ amor é facultativo, pois não cabe ao direito obrigar um pai a amar seu filho ou vice-versa, porém o cuidado é um dever do mesmo. Famílias, independentemente de sua formação são a base da nossa sociedade e é mais evidente que sua desestruturação prejudica toda a nação.

Com advento da Constituição Federal de 1988 e do Código Civil de 2002 houve a demonstração da importância da função social da família no ordenamento jurídico. Este princípio diz que as famílias devem ser protegidas na medida em que atenda a sua função social, sendo assim, aquele lugar capaz de propiciar a boa convivência de seus membros bem como a sua dignidade.

Mas a função social da família não se trata apenas de um direito que foi acolhido pelo ordenamento jurídico, mas trata-se de uma justificativa para a proteção da dignidade da pessoa humana, um dos princípios mais importantes da Constituição Federal de 1988.

Não há como negar então que o Direito usa dos princípios como um meio a se seguir, uma direção com a finalidade de alcançar um objetivo.

Sendo assim, a função social da família nada mais é que um modo de realizar e efetivar os princípios atinentes a evolução da dignidade da pessoa humana. 
A dignidade da pessoa humana é o primeiro fundamento de todo o nosso sistema, é o princípio que mostra a direção que deve seguir o intérprete do texto constitucional. O princípio da dignidade da pessoa humana é um fundamento da República Brasileira, encontrado no artigo $1^{\circ}$ da Constituição Federal de $1988 .{ }^{5}$

Flademir Jerônimo Belinati Martins, por sua vez, preceitua o princípio da dignidade da pessoa humana como sendo o alicerce de todo o nosso Estado Democrático de Direito. A Constituição Federal de 1988 fez com que a dignidade da pessoa humana passasse a ser um valor supremo da ordem jurídica-política, sendo assim, dizer que a dignidade da pessoa humana é um valor supremo, resulta no fato de que ela não é tão somente um princípio de ordem jurídica, mas também de ordem política, social e econômica. ${ }^{6}$

\begin{abstract}
Art. $1^{\circ}$ A República Federativa do Brasil, formada pela união indissolúvel dos Estados e Municípios e do Distrito Federal, constitui-se em Estado Democrático de Direito e tem como fundamentos:

I - a soberania;

II - a cidadania;

III - a dignidade da pessoa humana. ${ }^{7}$
\end{abstract}

De tal modo, é de fundamental importância identificar o princípio da dignidade da pessoa humana como sendo uma conquista advinda de problemas e atrocidades históricos-sociais que marcaram e continuam marcando a humanidade ao longo dos anos.

Rizzato Nunes em uma passagem de sua obra sobre o Princípio da Dignidade da Pessoa Humana diz que "Então se extrai dessa experiência histórica o fato de que a dignidade nasce com o indivíduo. $O$ ser humano é digno porque é." Sendo assim, toda pessoa tem direito a ter uma vida digna repleta de recursos que possibilitem a sua existência em meio a sociedade. ${ }^{8}$

\footnotetext{
${ }^{5}$ NUNES, Rizzatto. O princípio constitucional da pessoa humana: doutrina e jurisprudência. 3 ed. Rev. e ampl, - São Paulo. Saraiva. 2010, p. 30

${ }^{6}$ MARTINS, Flademir Jerônimo Belinati. Dignidade da pessoa humana: princípio constitucional fundamental. Curitiba: Juruá, 2003, p. 71

${ }^{7}$ Constituição Federal de 1988.

${ }^{8}$ NUNES, Rizzatto. O princípio constitucional da pessoa humana: doutrina e jurisprudência. 3 ed. Rev. e ampl, - São Paulo. Saraiva. 2010.
} 
A partir da redação do texto constitucional de 1988, podemos perceber que a prioridade do Estado passa-se a ser o ser humano, em todos os seus modos, tendo que ser a sua fonte de inspiração para criar direitos e deveres como também ser o seu fim.

O Constitucionalista exclui então a visão patrimonialista em todas as suas relações, sendo elas políticas, econômicas e sociais, para enfim estabelecer e voltar esta visão ao bem-estar e desenvolvimento do ser humano. Destarte, o Estado se constrói com base na pessoa humana e apenas para servi-la, propiciando as condições mínimas para a sua plena dignidade em meio a sociedade. ${ }^{9}$

Lembremos que o presente princípio foi expressamente previsto no texto de nossa Magna Carta e que tem a sua vigência estendida a outros capítulos da Constituição Federal, mostrando que a ordem econômica do pais tem como finalidade garantir uma existência digna a todas as pessoas encontrando seu fundamento legal no artigo 170, caput, Constituição Federal de 88, ou quando fundou o planejamento familiar com base no Princípio da Dignidade da Pessoa Humana conjuntamente com o Princípio da Paternidade Responsável que será estudada logo adiante e que encontra seu fundamento legal no artigo $226, \S 6^{\circ}$ e não podemos esquecer que fundou no artigo 227, caput, que a todas as crianças e adolescentes serão asseguradas a dignidade. A que se falar então, que após vários períodos históricos finalmente foi dado a dignidade da pessoa humana a atenção que o mesmo merecia.

Vale ressaltar que a dignidade da pessoa humana só obteve o seu reconhecimento após a Segunda Guerra Mundial, quando foi instituído expressamente nas Constituições após ter sido consagrado pela Declaração Universal da ONU em 10 de dezembro de 1948. Que traz em seu preambulo a seguinte passagem:

\footnotetext{
Considerando que o reconhecimento da dignidade inerente a todos os membros da família humana e de seus direitos iguais e inalienáveis é o fundamento da liberdade, da justiça e da paz no mundo. ${ }^{10}$
}

Também diz que todos reafirmaram na carta da ONU a fé nos direitos fundamentais, mais uma vez citando a dignidade da pessoa humana:

\footnotetext{
${ }^{9}$ MARTINS, Flademir Jerônimo Belinati. Dignidade da pessoa humana: princípio constitucional fundamental. Curitiba: Juruá, 2003, p. 72.

10 NAÇÕES UNIDAS NO BRASIL. Declaração dos Direitos Humanos. Disponível em: <http://www.onu.org.br/img/2014/09/DUDH.pdf〉. Acesso em 24 de maio de 2018.
} 
Considerando que os povos das Nações Unidas reafirmaram, na Carta da ONU, sua fé nos direitos humanos fundamentais, na dignidade e no valor do ser humano e na igualdade de direitos entre homens e mulheres, e que decidiram promover o progresso social e melhores condições de vida em uma liberdade mais ampla. ${ }^{11}$

Sem o intuito de formular um conceito para o princípio da dignidade da pessoa humana, a Mestra em Direito, Liane Maria Busnello Thomé nos traz um parágrafo que diz que:

Cada ser humano é merecedor de respeito e consideração, independente de crença, nível social, intelectual, opção sexual e maneira de enfrentar a vida. O simples fato de ser humano basta para que a sua dignidade seja garantida. ${ }^{12}$

Condizendo totalmente com o previsto no artigo $1^{\circ}$ da Declaração dos Direitos Humanos da ONU que diz "Todos os seres humanos nascem livres e iguais em dignidade e direitos. São dotados de razão e consciência e devem agir em relação uns aos outros com espírito de fraternidade.”

\section{O PRINCÍPIO DA PATERNIDADE RESPONSÁVEL}

O princípio da paternidade responsável está diretamente vinculado com o princípio da dignidade da pessoa humana, sendo que este é a fundação da estrutura familiar, pois, visa assegurar o desenvolvimento de todos os membros, especialmente a criança e o adolescente.

Observando atentamente o referido princípio podemos perceber que ele gera uma ideia de responsabilidade que deve ser examinada na formação da família.

O princípio da paternidade responsável tem a sua previsão legal no art. 226, $\$ 7^{\circ}$ da Constituição Federal de 1988 no qual diz expressamente:

Art. 226. A família, base da sociedade, tem especial proteção do Estado.

11 NAÇÕES UNIDAS NO BRASIL. Declaração dos Direitos Humanos. Disponível em: $<$ http://www.onu.org.br/img/2014/09/DUDH.pdf>. Acesso em 24 de maio de 2018.

${ }^{12}$ THOMÉ, Liane Maria Busnello. Princípio da dignidade da pessoa humana e mediação como instrumento de potencialização da dignidade nas rupturas dos casais em família. 2007. 149f. dissertação (Mestrado em Direito) - Faculdade de Direito, Pontifícia Universidade Católica do Rio Grande do Sul, Porto Alegre, 2007. 
[...] $\S 7^{\circ}$ Fundado nos princípios da dignidade da pessoa humana e da paternidade responsável, o planejamento familiar é livre decisão do casal, competindo ao Estado propiciar recursos educacionais e científicos para o exercício desse direito, vedada qualquer forma coercitiva por parte de instituições oficiais ou privadas.

O planejamento familiar é de livre decisão do casal e está intimamente ligado ao princípio da dignidade da pessoa, pois, os pais no momento de gerar seus filhos devem ter em mente se conseguirão dar-lhes uma vida digna e com todos os recursos necessários para um crescimento saudável. Aqui podemos citar tanto crescimento físico como psíquico.

Essa responsabilidade é de ambos os genitores da criança, sem exclusão de nenhum, podendo ser estendida também aos companheiros. A Lei $\mathrm{n}^{\circ}$ 9.253/96 regulamentou o assunto no tocante a responsabilidade do Poder Público em fase a entidade familiar.

Maria Berenice Dias fala a respeito do atual conceito de família, que é focalizado no afeto, e que demanda dos genitores o dever de criar e cuidar efetivamente seus filhos sem excluir-lhes o afeto necessário para o desenvolvimento pleno de sua personalidade humana, como deve ser. $\mathrm{O}$ afeto é um fator de tamanha importância na vida de qualquer ser humano, sendo que, a sua falta, pode causar um grande impacto nas crianças pelo fato delas usarem os pais como um verdadeiro espelho, eles querem ser como os pais e a falta do afeto poderia causar um ruptura extremamente grande na sua personalidade, podendo fazer a criança crescer e desenvolver uma personalidade totalmente diferente. ${ }^{13}$

Podemos citar uma passagem de Maria Berenice Dias, na qual ela menciona os resultados obtidos pela ciência no tocante ao psiquismo da criança e do adolescente e a sua importância.

A grande evolução das ciências que estudam o psiquismo humano acabou por escancarar a decisiva influência do contexto familiar para o desenvolvimento sadio de pessoas em formação. Não se

\footnotetext{
${ }^{13}$ DIAS, Maria Berenice. Manual de direito das famílias. - 9. Ed. rev., atual e ampl. de acordo com: Lei 12.344/2010 (regime obrigatório de bens): Lei 12.398/2011 (direito de visita dos avós). - São Paulo: Editora Revista dos Tribunais, 2013, p. 94.
} 
pode mais ignorar essa realidade, tanto que se passou a falar em paternidade responsável. ${ }^{14}$

De tal modo, a convivência dos pais com a criança ou adolescente não se trata de uma mera opção, eles têm o dever de estar presente na vida de seus filhos. Não há o que se falar em direito à visita, há a obrigação de conviver com eles e gerar um bom relacionamento onde qualquer pessoa de fora do núcleo familiar possa ver o amor e a confiança entre pai e filho.

Podemos dizer então que sempre que houver um dever dos pais, haverá um direito por parte do filho que está diretamente ligado a ele. O art. 227, da Constituição Federal de 1988, diz que é dever da família assegurar à criança e ao adolescente, o direito à vida, à saúde, à alimentação, à dignidade, o respeito, a convivência familiar e outros. Para que tais direitos sejam garantidos àqueles que os esperam, o Estado deve exigir condutas próprias do exercício da paternidade responsável.

Assim, podemos ver a ação conjunta entre os pais e o Estado para garantir a criança e o adolescente o seu pleno desenvolvimento.

\section{$5 \quad$ A RESPONSABILIDADE CIVIL}

A palavra Responsabilidade Civil tem sua origem no latim, mais precisamente da palavra "respondere" que transmite a concepção de que aquele que causar um dano a outrem, tanto na ação quanto na omissão, deverá responder pelo ato por ele praticado, a responsabilidade então obriga o agente causador do dano a restaurar o equilíbrio e reparar o dano que o mesmo causou.

O autor Carlos Roberto Gonçalves, explica a ideia que a palavra responsabilidade exprime:

Pode-se afirmar, portanto, que responsabilidade exprime ideia de restauração de equilíbrio, de contraprestação, de reparação de dano. Sendo múltiplas as atividades humanas, inúmeras são também as espécies de responsabilidade, que abrangem todos os ramos do

\footnotetext{
${ }^{14}$ DIAS, Maria Berenice. Manual de direito das famílias. - 9. Ed. rev., atual e ampl. de acordo com: Lei 12.344/2010 (regime obrigatório de bens): Lei 12.398/2011 (direito de visita dos avós). - São Paulo: Editora Revista dos Tribunais, 2013, p. 94.
} 
direito e extravasam os limites da vida jurídica, para se ligar a todos os domínios da vida social. ${ }^{15}$

Aquele que por ato lícito ou ilícito causar um dano a outrem, podendo este dano ser patrimonial, moral ou estético, deverá repara-lo, pois, este é um valor inerente a toda sociedade, o de não causar dano a outrem.

O código civil de 2002 em seu artigo 186 preceitua que o agente que por ação ou omissão, negligência ou imprudência causar danos ou violar direito de outrem comete ato ilícito, mesmo que o dano seja exclusivamente moral. ${ }^{16}$

A responsabilidade civil é o momento posterior a obrigação, pois, na obrigação há um vínculo jurídico, que une credor e devedor. Este vinculo jurídico corresponde a uma relação pessoal, de crédito e débito que posteriormente se extinguirá com o seu cumprimento. A obrigação pode ser constituída de inúmeras formas e deve ser adimplida de maneira espontânea, sem nenhum tipo de coação ou força externa. Quando não há o cumprimento ou o adimplemento desta obrigação, surge a responsabilidade, vale lembrar que está só surge quando o devedor não cumpre a obrigação anteriormente adimplida.

Toda via, há possibilidades de uma existir sem a outra. As dívidas contraídas em jogos, por exemplo, não há responsabilidade porque não é lícita, neste caso não pode condenar o devedor a cumprir com a obrigação.

\section{DANO MORAL NO CENÁRIO JURÍDICO BRASILEIRO}

No momento anterior a Constituição Federal de 1988, não havia o que se falar em reparação por dano moral, pois, não havia naquela época uma tese constituída e pacifica. De tal modo era impossível condenar alguém a reparação do mal praticado, quando este se tratava de danos imateriais, a jurisprudência não conseguia determinar o quantum, o valor que deveria ser pago a vítima.

\footnotetext{
${ }^{15}$ GONÇALVES, Carlos Roberto, Direito Civil Brasileiro, volume 6: Direito de Família, 9 ed. São Paulo: Saraiva, 2012, p. 21.

16 PLANALTO < http://www.planalto.gov.br/ccivil 03/leis/2002/110406.htm>. Acesso em 10/07/2018.
} 
Podemos encontrar uma divisão no dano, constituindo o dano moral direto e o dano moral indireto. $\mathrm{O}$ dano moral direto equivale a lesão de um interesse que ter por finalidade a satisfação de um bem imaterial (a vida, a integridade corporal ou psíquica, a liberdade, a honra, a intimidade, os sentimentos afetivos). Já o dano moral indireto equivale a lesão que provoca prejuízo em interesses não patrimoniais, devido a um dano de um bem patrimonial oriundo da vida intima da vítima.

$\mathrm{O}$ dano moral não atinge o bem patrimonial da pessoa, mas sim a pessoa em si. Atingindo os direitos da personalidade, encontrados nos $\operatorname{artigos~} 1^{\circ}$, III e $5^{\circ}$, V e X, da Constituição Federal de 1988. Constituem os direitos da personalidade, a honra, a dignidade, a intimidade, a imagem, o bom nome, e etc.

Diferentemente do dano patrimonial, que a sanção ao agente causador do dano é a responsabilidade pela recomposição do patrimônio, fazendo com que o agente indenize a vítima do evento lesivo, restituindo o bem ou pagando-lhe o valor devido do seu patrimônio. O dano moral, diz respeito a esfera intima da pessoa, não sendo possível então que seja realizada a recomposição do dano. O mal que lhe foi causado, a priori é irreversível, entretanto, a reparação do dano terá caráter sancionatório à conduta do agente causador do dano. Humberto Theodoro Junior diz que "Atribui-se um valor à reparação, com duplo objetivo de atenuar o sofrimento injusto do lesado e de coibir a reincidência do agente na prática de tal ofensa, mas não como eliminação mesma do dano moral." 17

Já Maria Helena Diniz, que o critério para se diferenciar o dano patrimonial do dano moral não poderá ser apenas a natureza do dano, mas sim o interesse, isto é, a repercussão que o dano tem sobre o lesado, para então assim conseguir falar em dano moral. ${ }^{18}$

Esclareça-se que a determinação da reparação, nem sequer consegue colocar um valor a dor e o sofrimento que a vítima foi imposta, portanto, a doutrina e a jurisprudência tiveram que encontrar meios que fizessem com que a reparação atenuasse, não integralmente, mas em partes as consequências advindas do evento lesivo. Como por exemplo no abandono afetivo, como poderia os tribunais darem um valor a dor que a criança sentiu e sente, por não ter o pai consigo.

\footnotetext{
${ }^{17}$ JÚNIOR, Humberto Theodoro. Dano Moral. 1998, Editora Om, p. 3.

${ }^{18}$ DINIZ, Maria Helena. Curso de Direito Civil Brasileiro, v.7: Responsabilidade Civil. 31. Ed. Rev. e atual - São Paulo: Saraiva, 201, p. 91.
} 
Maria Berenice Dias nos mostra que a responsabilidade civil advinda das relações afetivas deveria ter por base a frase de Saint-Exupéry: és responsável por quem cativas. A dor então, mesmo sendo um fator subjetivo serve como justificativa para uma pretensão de indenização por danos morais. ${ }^{19}$

Por outro lado, a indenização por danos morais acabou-se por ser a solução para a maioria dos males que a sociedade era imposta. Está sendo então estudada uma possibilidade de ampliar o instituto da responsabilidade civil. Tirando o foco do elemento que constitui o fato ilícito, para focar na reparação do dano injusto. Com a ampliação do instituto estão havendo mais chances de reconhecer a existência de danos que ensejem a reparação, está sendo evidenciado o dano moral em qualquer situação que cause desconforto a pessoa.

De tal modo, está premissa migrou para o campo do Direito das Famílias, mudando a responsabilidade para o âmbito do vínculo afetivo.

Portanto, a reparação do dano moral deve obedecer ao princípio da satisfação compensatória, porque o quantitativo indenizatório a ser atribuído ao evento lesivo não pode ser similar a um "preço", pois é difícil colocar um preço na dor, angustia e sofrimento, a indenização então deverá ser capaz de amenizar o sofrimento a que a vítima foi imposta ou compensar pela ofensa aos seus direitos da personalidade.

\section{NEXO DE CAUSALIDADE COMO FATO PRINCIPAL PARA A CONDENAÇÃO}

O nexo causal é de extrema importância no tocante a responsabilidade civil, pois é a partir dele que poderá ser identificado os outros elementos que a compõem, o nexo de causalidade é o liame que une a conduta do agente e o dano por ele produzido.

Dentre os vários conceitos que podemos encontrar, Silvio Venosa diz que "o conceito de nexo causal, nexo etiológico ou relação de causalidade deriva das leis naturais." Porque é o elemento que une

\footnotetext{
${ }^{19}$ DIAS, Maria Berenice. Manual de direito das famílias. 9. Ed. rev., atual e ampl. de acordo com: Lei 12.344/2010 (regime obrigatório de bens): Lei 12.398/2011 (direito de visita dos avós). São Paulo: Editora Revista dos Tribunais, 2013, p. 86.
} 
a conduta a ação do agente, sendo assim, é mediante a analise desta mesma relação que se identifica quem causou o dano a vítima. ${ }^{20}$

Por ser um elemento de suma importância, portanto indispensável, é dever da vítima conseguir identificar o nexo de causalidade para deste modo conseguir a compensação decorrente do dano sofrido.

A priori é substancial que que seja analisado se o agente deu causa ou não ao dano ocorrido, para que logo após seja apurado se ele agiu com culpa ou não.

\footnotetext{
"Em síntese, é necessário que o ato ilícito seja a causa do dano, que o prejuízo sofrido pela vítima seja resultado desse ato, sem o que a responsabilidade não correrá a cargo do autor material do fato. Daí a relevância do chamado nexo causal. Cuida-se, então, de saber quando um determinado resultado é imputável ao agente; que relação deve existir entre o dano e o fato para que este, sob a ótica do Direito, possa ser considerado causa daquele". ${ }^{21}$
}

Existem três teorias que dizem respeito ao nexo de causalidade que são teoria da equivalência das condições (sine qua non); teoria da causalidade adequada e teoria do dano direto ou imediato ou teoria da interrupção do nexo causal.

A teoria da equivalência das condições ou então chamada de sine qua non não foi adotada pelo sistema brasileiro, em vista de aumentar muito o nexo de causalidade, pois, está teoria enuncia que todos os fatos relacionados ao evento que gerou o dano geram responsabilidade civil. Diz então, que o evento danoso não teria acontecido se não fosse a presença de todas condições que lhe foram identificadas.

Já a teoria da causalidade adequada, que foi desenvolvida por Von Kries, segundo está teoria deve se fazer a identificação de uma possível causa, aquela que produziu o dano, somente o fato que levou a produzir o dano é que poderá ensejar em responsabilidade civil, devendo a compensação está estritamente ligada ao fato danoso. Está teoria pode ser encontrada nos arts. 944 e 945 do Código Civil de 2002. ${ }^{22}$

E por fim a teoria do dano direto ou imediato ou interrupção do nexo causal, a qual diz que quando houver violação de algum direito por

\footnotetext{
${ }^{20}$ VENOSA, Silvio de Salvo. Direito Civil: Obrigações e responsabilidade civil. 17. ed. São Paulo: Atlas, 2017, p. 500.

${ }^{21}$ FILHO, Sergio Cavalieri. Programa de Responsabilidade Civil. 8 ed. São Paulo: Atlas, 2008, p. 46.

${ }^{22}$ TARTUCE, Flávio. Manual de Direito Civil: Volume único. 5. ed. Rev., atual. e ampl. São Paulo: Método, 2015, p. 389.
} 
parte do credor de dívida ou de terceiro interessado, haverá a interrupção do nexo de causalidade e tendo como consequência a irresponsabilidade do agente. Teoria também que pode ser encontrada no art. 403 do Código Civil de 2002.

As duas últimas teorias já foram usadas nos tribunais superiores e inferiores, por tanto não há um entendimento dizendo qual deve ser adotada, pois ambas integram o Código Civil de 2002. Há um julgado do Superior Tribunal de Justiça que afirmou que ambas as teorias são sinônimas (STJ, REsp 325.622/RJ, Rel. Min. Carlos Fernando Mathias (Juiz Federal Convocado do TRF 1. ${ }^{\text {a }}$ Região), Quarta Turma, j. 28.10.2008, DJe 10.11.2008). Não sendo correta tal afirmação pois há diferenças substanciais em cada uma destas teorias.

O nexo de causalidade é um elemento substancial para conseguirmos identificar o abandono afetivo, pois, a partir dele concluiremos que a conduta omissiva do genitor deu causa aos danos sofridos posteriormente pelo seu filho ou filhos.

Sendo comprovado que a falta de convívio com o filho pode gerar danos extensivos e muitas vezes irreparáveis, pois, comprometem todo o desenvolvimento pleno e saudável da criança, a conduta omissiva do pai produz dano afetivo que é passível de compensação monetária, desde que não é possível obrigar alguém a amar outrem.

Após a comprovação que há o nexo ligando a conduta do pai e os danos sofridos pela criança, o pai poderá perder o poder familiar por caracterizar o abandono afetivo, segundo o art. 1.638, inciso II do Código Civil de 2002 que diz:

\footnotetext{
Art. 1.638. Perderá por ato judicial o poder familiar o pai ou a mãe que:

I - Castigar imoderadamente o filho;

II - Deixar o filho em abandono;

III - Praticar atos contrários à moral e aos bons costumes;

IV - Incidir, reiteradamente, nas faltas previstas no artigo antecedente.

V - Entregar de forma irregular o filho a terceiros para fins de adoção.
}

Porém, a perda do poder familiar muitas vezes nem chega a ser uma penalização eficiente por te produzido o abandono afetivo, pois, para o pai pode se tornar uma bonificação pelo mesmo, já que este não queria conviver como filho. 
Maria Helena Diniz usando dos dizeres de Rodrigo da Cunha Pereira, que foi o primeiro jurista a levar a questão do abandono afetivo para apreciação na justiça, entende que o abandono deve ser tratado como uma lesão extrapatrimonial a um interesse jurídico tutelado, que foi gerado pela omissão do genitor enquanto exercia o poder familiar, configurando ato ilícito passível de compensação material. ${ }^{23}$

\section{ANALISE DE CASOS JULGADOS PELOS SUPERIORES TRIBUNAIS DE JUSTIÇA}

Se tratando de um tema ainda recente no âmbito jurídico brasileiro, o abandono afetivo depende das decisões dos julgadores referente a este tema, como magistrados, desembargadores e etc. Desta forma, será feita uma análise de jurisprudências pertinentes a este tema.

Há um grande conflito referente ao abandono afetivo, pois, algumas decisões dos tribunais dizem que há a possibilidade da compensação por abandono e outras tendem a dizer que é impossível que tal compensação ocorra.

O Superior Tribunal de Justiça entende que embora presente todos os requisitos necessários para a configuração da responsabilidade civil por abandono afetivo, a descabida a compensação, tendo em vista que mediante uma análise do mesmo tribunal a omissão causada pelo pai da criança não caracteriza ato ilícito, como é mostrada na decisão prolatada pelo Relator Carlos Henrique Miguel:

\footnotetext{
"CIVIL E PROCESSUAL. AÇÃO DE INVESTIGAÇÃO DE PATERNIDADE E RECONHECIMENTO. DANOS MORAIS REJEITADOS. ATO ILÍCITO NÃO CONFIGURADO. I. Firmou o Superior Tribunal de Justiça que "A indenização por dano moral pressupõe a prática de ato ilícito, não rendendo ensejo à aplicabilidade da norma do art. 159 do Código Civil de 1916 o abandono afetivo, incapaz de reparação pecuniária." Recurso negado. (TJ-SP - APL: 56888020108260619 SP 000568880.2010.8.26.0619, Relator: Carlos Henrique Miguel Trevisan, Data de Julgamento: 29/11/2012, $4^{\text {a }}$ Câmara de Direito Privado, Data de Publicação: 04/12/2012) grifo nosso.
}

\footnotetext{
${ }^{23}$ DINIZ, Maria Helena. Curso de Direito Civil Brasileiro, v.7: Responsabilidade Civil. 31. Ed. Rev. e atual São Paulo: Saraiva, 2017, p. 472.
} 
Desta mesma forma, se manifesta o Relato Luiz Felipe Brasil Santos que se manifesta dizendo que não há o que se falar em compensação material já que nunca houve uma relação de proximidade entre pai e filho, o que deste modo não caracteriza ato ilícito por abandono afetivo, como pode ser:

\begin{abstract}
APELAÇÃO CÍVEL. ABANDONO AFETIVO. INDENIZAÇÃO POR DANO MORAL À FILHA. DESCABIMENTO. AUSÊNCIA DE ATO ILÍCITO ENSEJADOR DA INDENIZAÇÃO. AGRAVO RETIDO NÃO CONHECIDO.1. Não é conhecido o agravo retido, por não ter sido postulada sua apreciação ao ensejo da apelação.2. No direito de família, o dano moral é, em tese, cabível. No entanto, imprescindível que haja a configuração do ato ilícito.3. É preciso distinguir duas situações possíveis. A primeira consiste em que, tendo o filho sido criado pelo genitor dentro de determinado padrão de afeto e cuidado, vem o casal a separar-se e, a partir daí o pai se comporta como se a separação do casal conjugal significasse também o rompimento da relação parental (com os filhos). Nesse caso, é razoável que seja esse comportamento objeto de reparação por dano moral, porque houve um rompimento injustificável da relação pai-filho, que antes era consolidada. Na segunda hipótese, que é a dos autos, jamais houve qualquer relação afeto e cuidado por parte do genitor, que somente veio a ser declarado tal por decisão judicial, no bojo de uma ação investigatória. Neste contexto, não se justifica a imposição de reparação moral, porque jamais existiu um laço de cuidado e afeto entre pai e filho. $E$ esse laço não pode ser imposto por decisão judicial. NÃO CONHECERAM DO AGRAVO RETIDO. NEGARAM PROVIMENTO AO PRIMEIRO APELO E DERAM-NO AO SEGUNDO. UNÂNIME. (Apelação Cível $\mathrm{N}^{\circ}$ 70063562151, Oitava Câmara Cível, Tribunal de Justiça do RS, Relator: Luiz Felipe Brasil Santos, Julgado em 18/06/2015).
\end{abstract}

Mesmo prevalecendo nos Tribunais que foram analisados de que não há o que se falar em reparação por danos morais decorrente do abandono afetivo, recentemente houve a primeira decisão favorável ao tema, no qual a Desembargadora Nancy Andrighi diz que o não cuidar do filho implica em um ato ilícito, pois, é dever do pai zelar pelo seu filho e prover-lhe todos os meios necessários para o seu crescimento, e que mediante a omissão, deve sim ser caracterizado a responsabilidade civil e como consequência a compensação material pelo dano causado, julgamento no qual foi parcialmente provido. Veja-se:

CIVIL E PROCESSUAL CIVIL. FAMÍLIA. ABANDONO AFETIVO. COMPENSAÇÃO POR DANO MORAL. POSSIBILIDADE. 1. Inexistem restrições legais à aplicação das regras concernentes à responsabilidade civil e o consequente dever de indenizar/compensar no Direito de Família. 2. O cuidado como 
valor jurídico objetivo está incorporado no ordenamento jurídico brasileiro não com essa expressão, mas com locuções e termos que manifestam suas diversas desinências, como se observa do art. 227 da $\mathrm{CF} / 88$. 3. Comprovar que a imposição legal de cuidar da prole foi descumprida implica em se reconhecer a ocorrência de ilicitude civil, sob a forma de omissão. Isso porque o non facere, que atinge um bem juridicamente tutelado, leia-se, o necessário dever de criação, educação e companhia - de cuidado importa em vulneração da imposição legal, exsurgindo, daí, a possibilidade de se pleitear compensação por danos morais por abandono psicológico. 4. Apesar das inúmeras hipóteses que minimizam a possibilidade de pleno cuidado de um dos genitores em relação à sua prole, existe um núcleo mínimo de cuidados parentais que, para além do mero cumprimento da lei, garantam aos filhos, ao menos quanto à afetividade, condições para uma adequada formação psicológica e inserção social. 5. A caracterização do abandono afetivo, a existência de excludentes ou, ainda, fatores atenuantes - por demandarem revolvimento de matéria fática - não podem ser objeto de reavaliação na estreita via do recurso especial. 6. A alteração do valor fixado a título de compensação por danos morais é possível, em recurso especial, nas hipóteses em que a quantia estipulada pelo Tribunal de origem revela-se irrisória ou exagerada. 7. Recurso especial parcialmente provido. (REsp 1159242/SP, Rel. Ministra NANCY ANDRIGHI, TERCEIRA TURMA, julgado em 24/04/2012, DJe 10/05/2012) grifo nosso.

Diante do estudo feito, pode-se observar que vários tribunais tendem a julgar que não houve o abandono parental por não ter sido causado nenhum dano a vítima, porém, deve ser analisado e levado em conta o nexo de causalidade que une a conduta omissiva do agente causador do dano com o dano sofrido pela vítima.

É de suma importância que o Estado, como detentor do jus puniendi em aplicar a compensação material quando está for cabida, para que possa assim, evitar futuros casos, deste modo, a criança poderá ter seu desenvolvimento pleno e saudável.

\section{CONCLUSÃO}

Há um crescimento exponencial de casos que estão indo para a apreciação do Poder Judiciário, para conseguir assim uma compensação material pelos danos sofridos, danos estes intimamente ligados aos direitos da personalidade, já que por não ter o pai por perto acarreta diversas consequências, como por diversas vezes, problemas na escola ligado aos amigos da criança. 
Conclui-se que a conduta omissiva do genitor é o principal fator do abandono, pois, o genitor no momento em que se omite tanto em dar afeto e carinho a criança que tanto necessita, lhe priva muitas vezes do que é necessário para que esta tenha o crescimento que espera.

Cabe então aos tribunais superiores por fim, identificarem a conduta omissiva do agente causador do dano e identificar o nexo de causalidade entre esta conduta e o dano sofrido pela vítima, devendo constatar se este é psíquico ou material para mensurar o quantum será pago como compensação, pois, aqui não há o que se falar em indenização, já que é impossível dar preço ao amor e afeto.

\section{REFERENCIAS BIBLIOGRÁFICAS}

AMBITO JURIDICO. Disponivel em: http://ambitojuridico.com.br/site/?n_link=revista_artigos_leitura\&artigo_id=14099. Acesso em 21 de Agosto de 2018.

DIAS, Maria Berenice. Manual de direito das famílias. - 9. Ed. rev., atual e ampl. de acordo com: Lei 12.344/2010 (regime obrigatório de bens): Lei 12.398/2011 (direito de visita dos avós). - São Paulo: Editora Revista dos Tribunais, 2013.

DINIZ, Maria Helena. Curso de Direito Civil Brasileiro, v.7: Responsabilidade Civil. - 31. Ed. Ver. E atual - São Paulo: Saraiva, 2017.

FILHO, Sergio Cavalieri. Programa de Responsabilidade Civil. $8^{\circ}$ ed. São Paulo: Atlas, 2008.

GONÇALVES, Carlos Roberto, Direito Civil Brasileiro, volume 6: Direito de Família, 9a Edição, São Paulo - Saraiva, 2012.

JÚNIOR, Humberto Theodoro. Dano Moral. 1998, Editora Om.

MARTINS, Flademir Jerônimo Belinati. Dignidade da pessoa humana: princípio constitucional fundamental. Curitiba: Juruá, 2003.

NAÇÕES UNIDAS NO BRASIL. Declaração dos Direitos Humanos. Disponível em: http://www.onu.org.br/img/2014/09/DUDH.pdf. Acesso em 24 de maio de 2018.

NUNES, Rizzatto. O princípio constitucional da pessoa humana: doutrina e jurisprudência/ Rizzatto Nunes. - $3^{\mathrm{a}}$ ed. Ver, e ampl, - São Paulo. Saraiva. 2010.

PLANALTO. Disponível em: http://www.planalto.gov.br/ccivil_03/leis/2002/110406.html acesso em 10 de Julho de 2018 as 11:10 
PEREIRA, Rodrigo da Cunha, Direito de Família: uma abordagem psicanalítica. $-4^{\text {a }}$. Ed. - Rio de Janeiro: Forense, 2012.

SARLET, Ingo Wolfgang. Dignidade da pessoa humana e direitos fundamentais na Constituição Federal de 1988. 4.ed. ver. atual - Porto Alegre: Livraria do Advogado.

TARTUCE, Flávio. Manual de Direito Civil: Volume único. 5a. Ed. rev., atual. e ampl. - São Paulo: Método, 2015.

TEIXEIRA, Ana Carolina Brochardo. Responsabilidade Civil e Ofensa à Dignidade Humana. Revista Brasileira de Direito de Família. Porto Alegre, 36ª Edição.

THOMÉ, Liane Maria Busnello. Princípio da dignidade da pessoa humana e mediação como instrumento de potencialização da dignidade nas rupturas dos casais em família. 2007. 149f. dissertação (Mestre em Direito) - Faculdade de Direito, Pontifícia Universidade Católica do Rio Grande do Sul, Porto Alegre, 2007.

VENOSA, Silvio de Salvo. Direito Civil: Obrigações e responsabilidade civil/ Silvio Venosa. - 17. Ed. - São Paulo: Atlas, 2017. 